\title{
ПРОЕКТ НІЖИНСЬКОЇ ГІМНАЗЇ̈ ВИЩИХ НАУК ПРОФЕСОРА АФАНАСІЯ СТОЙКОВИЧА 1805 РОКУ
}

\author{
В. Л. Маслійчук
}

Маслійчук В. Л. Проект Ніжинської гімназії вищих наук професора Афанасія Стойковича 1805 року. Публікація пропозицій професора Харківського імператорського університету Афанасія Стойковича розкриває його педагогічні погляди. План створення Ніжинської гімназії свідчить про ознайомлення науковця і педагога сербського походження з провідними європейськими педагогічними вченнями, обізнаність 3 основною літературою з гуманітарних та точних наук, спроби удосконалити освіту в Російській імперії. Цей твір дає змогу ширше висвітлити діяльність непересічної постаті в ранній історії Харківського імператорського університету.

Ключові слова: педагогіка; Харківський університет; Афанасій Стойкович; Ніжинська гімназія; едукаційні проекти.

Маслийчук В. Л. Проект Нежинской гимназии высших наук профессора Афанасия Стойковича 1805 года. Публикация предложений профессора Харьковского императорского университета Афанасия Стойковича расскрывает его педагогические взгляды. План создания Нежинской гимназии свидетельствует об ознакомлении ученного и педагога сербского происхождения с ведущими европейскими педагогическими взглядами, знанием основной литературы по гуманитарным и точным наукам, о попытках усовершенствовать образование в Российской империи. Проект дает возможность более широко представить деятельность этой яркой личности в ранней истории Харьковского императорского университета.

Ключевые слова: педагогика; Харьковский университет; Афанасий Стойкович; Нежинская гимназия; образовательные проекты.

Masliychuk V. L. The Project of Nizhyn Gymnasium of Higher Sciences by Professor Athanasius Stojkovich of 1805. The publication of proposals of professor of Kharkiv Imperial University Athanasius Stojkovich reveals his pedagogical views. The plan of creation of Nizhyn gymnasium indicates acquaintance of the scholar and teacher of Serbian origin with a leading European academic teachings, his awareness of the major literature on humanities and the exact sciences, and attempts to improve education in the Russian Empire. The project enables wider elucidation of the activity of this bright figure in the early history of Kharkiv Imperial University. projects.

Keywords: pedagogy; Kharkiv University; Athanasius Stojkovich; Nizhyn gymnasium; educational

Однією з основних проблем історії освіти на українських землях другої половини XVIII - початку XIX ст. $є$ наявність певної кількості планів та проектів щодо заснування й функціонування тих чи тих навчальних закладів ${ }^{1}$. Для історика освіти навіть нереалізовані проекти дають досить значний матеріал для розуміння поширення ідей Просвітництва на цих теренах, умов учительської праці та поглядів на значення освіти. До всього, ці проекти містять чимало педагогічних зауважень і пропозицій, важливих для розуміння засад сучасної педагогіки.

Окремим питанням може бути роль вихідців з балканських країн у створенні навчальних проектів або й, ширше, загалом життя і діяльність діячів освітньої галузі з іммігрантів у тогочасних умовах на території підімперської України. Серби, хорвати, чорногорці були причетні до низки перетворень та реформ у часи становлення освітньої системи Російської імперії. Власне, відому училищну реформу в 80-х pp. XVIII ст. здійснював серб Федір Янкович де Мірієво 2 . На території України одним із перших освітніх діячів сербського походження був директор училищ Чернігівського намісництва 1793-1796 pp. Стефан Ожеговець де Винарець ${ }^{3}$. Вихідців із Балкан, особливо $з$ підвладної Австрійській імперії частини, бачимо в Харківському навчальному окрузі під час проведення освітньої реформи на початку XIX ст. Досить помітними постатями, зокрема, були вчителі, філософи, а потому й викладачі Харківського імператорського університету Сава Милинович та 
Андрій Дудрович (загалом в університеті у перше десятиліття його існування викладали сім вихідців із Балкан) ${ }^{4}$. Маючи вже непогану університетську освіту, сербські вчителі та науковці залишили доволі помітний слід в історії шкільництва.

Окремою і досить значною постаттю в освіті був професор Афанасій (Атанасіє) Стойкович (1773-1832). Стойкович походив з містечка Руми (Воєводина) і протягом юності й молодості здійснив серйозну мандрівку по університетах Австрійської імперії та Німеччини, насамкінець навчався в Геттингені, а докторський ступінь отримав у Тюбінгені $i^{5}$ Перед приїздом до Харкова напередодні відкриття університету одним із перших серед запрошеної професури в 1803 р. Стойкович уже мав непогані здобутки (поміж тим і кілька художніх творів сербською мовою та тритомний курс фізики), атестати від найкращих німецьких професорів ${ }^{6}$. Науковець став першим професором фізики Харківського імператорського університету (посів кафедру) та деканом відділення фізичних і математичних наук, увійшов до училищного комітету. Афанасій Стойкович залишив по собі дуже істотний слід передусім завдяки своєму ректорству в Харківському університеті (1807-1808; 1811-1813рр.) і добре описаній справі щодо його зловживань ${ }^{7}$ За обгрунтованим звинуваченням ад'юнкта та архітектора Євгенія Васильєва, Стойкович, користуючись ректорською владою, займався перепродажем вина та іншими комерційними оборудками, незаслужено утискав ад'юнкта. Суд над Стойковичем відбувся з численними порушеннями університетського статуту. Справа була дуже гучною, про неї пам'ятали навіть через шістдесят років ${ }^{8}$. Найголовніше, що скаргу Васильєва розглядали Вчена рада і правління університету, усунувши ректора. Формально Стойковича було звільнено з посади ректора в 1813 р. за «станом здоров’я», з часом він покинув Харків і помер у Петербурзі 1832 p. ${ }^{9}$

Серед істориків Харківського університету склалося ставлення до Стойковича як до такого собі пройдисвіта («ловкий и искусный диалектик»), людини без моралі, компілятоpa, майстра інтриги ${ }^{10}$, «першого іноземного ректора, вигнаного 3 ганьбою» ${ }^{11}$. Однак таке ставлення $є$ дещо упередженим. Важко сперечатися про грунтовність звинувачень чи резонанс справи щодо спекуляцій ректора, однак слід зважити на загальний контекст провин Стойковича та критику окремих джерел. Основну характеристику Афанасія Стойковича складено на основі особистого джерела - спогадів Крістофа Дітріха Роммеля; офіційний матеріал, переказаний Миколою Лавровським, дещо відрізняється від суворих Роммелевих оцінок. Крістоф Роммель і Йоганн Шад були тими двома іноземцями, які разом із російською професурою виступили проти ректора Стойковича 1813 p. $^{12}$ Як один із перекладачів і коментаторів спогадів Роммеля українською мовою, маю зазначити, що ці спогади, написані професором на батьківщині на схилі віку, багато в чому є засобом виправдатися щодо своєї втечі від бонапартистської держави в Гессені, невдалого викладання в Харкові та покинутої в Росії дружини ${ }^{13}$. Але навіть характеристика від Роммеля не $є$ однозначною, він сміливо називає Стойковича «нашим добрим і злим демоном», передає чутки про компілятивний характер його творів та зазначає про корупційну діяльність, але визнає його освіченість і причетність до створення наукового товариства та парубоцького клубу для професорів ${ }^{14}$. Щодо моральних якостей і наукового доробку перших харківських професорів можна навести чимало негативних прикладів, користування особистісними спогадами містить багато пасток для історика.

Це окрема тема для дискусій, однак дещо зупинимося на цьому досить важливому та дражливому питанні ранньої історії Харківського імператорського університету. За останні роки світ побачили три важливих видання спогадів, прямо пов'язаних з історією Харківського університету тих часів: насамперед, це мемуари професора Людвіга Якоба ${ }^{15}$; досить уривкові але й насичені деталями спогади Романа Цебрикова, який відвідав свою батьківщину, Харків, у час ректорства Афанасія Стойковича ${ }^{16}$; нотатки Івана Лобойка, харківського студента, а пізніше віленського професора ${ }^{17}$. Тобто перед дослідником - спогади колеги, стороннього спостерігача та студента. У всіх спогадах Стойкович як професор і організатор науки оцінений позитивно. Роман Цебриков із християнським моралізаторством засуджує торговельні оборудки ректора та його користолюбство, але визнає, що охоче читав праці цього науковця і дуже шкодує, що Стойкович покинув наукову працю ${ }^{18}$. Людвіг Якоб теж досить суворий в оцінці Стойковича, проте визнає, що загальна освіченість Стойковича була блискучою (vortrefflich), він чудово володів мовами 
(«говорив із німцями як німець, а з росіянами як росіянин»), але мораль цього чоловіка була не суворою, він мав надмірні амбіції стати ректором. Ворожнеча щодо Стойковича відчувалась уже під час приїзду професора Якоба до Харкова у 1807 р., йому негативно характеризували Стойковича перед знайомством, але надалі для будь-яких образ не було підстав, навпаки - у ставленні до себе Якоб спостерігав від Стойковича лише позитив ${ }^{19}$. Іван Лобойко взагалі дуже позитивно характеризує Стойковича як хорошого викладача та адміністратора ${ }^{20}$. Попри халепу, в яку вскочив Стойкович 1813 р., автори спогадів визнають його науковий та викладацький талант. Тобто переносити мемуарні характеристики на поле діяльності тих чи інших осіб варто з певною обережністю.

Торгівля Стойковича вином, виписаним з Угорщини й перевезеним за професорськими квотами безмитно, річ незаперечна, але й доволі плутана. Афанасій Стойкович виявився жертвою не стільки свого користолюбства, скільки своєї політики посередництва між партіями російських і німецьких професорів. Іван Лобойко називає Стойковича взагалі «серед німців» ${ }^{21}$. Після подій 1812 р. було зрозуміло, що німецька партія в програші. А своїми оборудками під час обмеженого фінансування університету та знецінення грошей у період війни 1812 р. Стойкович налаштував проти себе як одних, так і інших. Між тим, у дуже грунтовній праці з історії Харківського університету Дмитра Багалія, який негативно ставився до діяльності Стойковича, наведено приклади ксенофобії щодо іноземців, студентів та професорів після перемоги над Наполеоном ${ }^{22}$. Ректор усе ж залишався іноземцем, проти якого спрямовувалася вся негативна критика. Але відставка ректора внаслідок рішення Вченої ради та правління - досить незвична річ для тогочасної освітньої системи Російської імперії. Зважену оцінку тим подіям дав історик Микола Лавровський ще до праць Дмитра Багалія, поєднавши у своїй розвідці дві статті - про ректорство Афанасія Стойковича та іншого пізнішого вигнанця Йоганна Шада ${ }^{23}$.

Роль Стойковича в постанні та першому десятилітті існування університету незаперечна, він входив до трійки провідних професорів. Крім усього, Стойкович дійсно мав хороші організаторські здібності, що давало йому змогу обійняти посаду ректора ще в 1807-1808 рр. Так само, мабуть, слід схилитися до оцінок, висловлених щодо особи Афанасія Стойковича Сергієм Страшнюком: серб-ректор дійсно був дуже визначною постаттю в історії університету - першим філософом-матеріалістом в університеті, хорошим викладачем фізики (автор загальноімперського підручника, створив новітній на той час фізичний кабінет), постаттю, яка серйозно зважала на проблеми харківської екології. Тут варто погодитися з оцінкою одного з істориків університету Людовіка Яновського, що Стойкович був «прекрасною науковою силою» ${ }^{24}$. I, слід додати, діячем, який прагнув зробити внесок і в організацію навчального процесу, і в педагогічну практику. Треба відзначити дійсно педагогічне спрямування в діяльності Стойковича - його перша відома робота (з фізики сербською мовою), значна частина його праць харківського періоду мають пояснювальний, підручниковий характер («Начальные основания умозрительной и опытной физики» (1809), «Начальные основания физической географии» (1813), «Начальные основания физической астрономии» (1813)). Та найцікавіша його праця в цій царині вийшла в Петербурзі у 1831 р., напередодні смерті професора: «О неблагоразумном и превратном домашнем воспитании детей: В примерах по способу Сальцмана. Книга для родителей и наставников в двух частях» (СПб., 1831).

Щойно почав функціонувати Харківський навчальний округ, професор Стойкович активно долучився до діяльності з заснування нових навчальних закладів. Досить цікавою $\epsilon$ детально описана Дмитром Багалієм поїздка Стойковича до Одеси в 1804 р. щодо відкриття там комерційного училища, професор мав пропозиції створення «індустріальних» училищ, які бачив у Німеччині. Однак Стойкович визнав непридатним, через брак кадрів та фінансування, робити таке училище в Одесі ${ }^{25}$.

Поява одного $з$ документів іде в річищі реформ у Російській імперії в освітній сфеpi на початку XIX ст. Унаслідок цих реформ було утворено великий Харківський навчальний округ, що мав опікуватися освітою в кількох губерніях, та Харківський імператорський університет (урочисто відкритий у січні 1805 р.). Шляхетство «Малоросії» (колишньої козацької автономії) було знехтуване в його прагненнях мати власний навчальний заклад. Тому брат колишнього канцлера імперії Олександра Безбородька Ілля, вочевидь, не без сприяння «малоросів» у Петербурзі вирішив офірувати дуже значну 
суму, заповідану на благодійність, на відкриття в Ніжині закладу для шляхтичів. Це досить яскраво підтверджує лист міністра внутрішніх справ Віктора Кочубея до Іллі Безбородька в липні 1805 р. про «училище некоторым образом университету свойственное... как Малороссия университета не имеет, да и дворянския училища, на которых в обеих губерниях до миллиона дать хотели, состоятся не могут, быв несообразны общей системе для училищ принятой» ${ }^{26}$. Суми пожертв на гімназію і зобов'язання щодо подальших фінансувань та забезпечень від Безбородьків були дуже істотними (Безбородько вже мав 70000 рублів і зобов'язувався щороку вносити по 20 000, крім того, надавав будинок 3 садом, цеглу, щорічно ще 15000 рублів із помість та роботу 3000 кріпосних душ із «Малоросії» $)^{27}$. На основі чуток викладач Київського головного народного училища та історик Максим Берлинський навіть попросився викладати в новий заклад ${ }^{28}$. Перед Харківським імператорським університетом було поставлено завдання забезпечити навчальний процес для цього училища. Розробити план для навчання в Ніжині взявся професор Афанасій Стойкович. Треба визнати, що проект Стойковича так і не було реалізовано, будівництво гімназійних приміщень, незважаючи на добре фінансування, затяглося на роки. У часи свого ректорства Стойкович, щоправда, намагався прискорити будівництво та відкриття гімназії ${ }^{29}$, однак війна 1812 р. відтягла реалізацію цього освітнього проекту. Гімназію було відкрито вже після відставки Стойковича і смерті основного жертводавця Іллі Безбородька, в 1820 р., завдяки активній діяльності спадкоємця Безбородьків Олександра Кушелєва-Безбородька ${ }^{30}$.

Треба розуміти кілька важливих нюансів з історії освіти в Ніжині, щоб схарактеризувати сміливі пропозиції професора. Передусім, Ніжин дійсно був найбільшим містом Лівобережної України, з численною грецькою колонією, тобто позірно якнайдужче пов'язаним із Балканами, рідною для Стойковича стихією. Це дуже яскраво виявилося пізніше, в добу сумнозвісного ректорства Стойковича, коли грецька громада Ніжина офірувала значну суму на відкриття в Ніжині грецького училища, ректор дуже сприяв цій ініціативі ${ }^{31}$ i навіть особисто їздив до Ніжина ${ }^{32}$.

Друга заувага: на відміну від жертводавців та представників шляхетства, представники Харківського університету (у тому числі Стойкович, як побачимо) мислили ширше, хотіли, щоб заклад був відкритим не лише для дворянських дітей, але й для інших «сословий». Це видно вже в листі-реакції на відкриття гімназії попечителя Харківського навчального округу Северина Потоцького ${ }^{33}$ i, власне, $з$ перших рядків рапорта щодо складання навчального плану Стойковича (наведеного нижче).

План Ніжинської гімназії Стойковича я виявив у фонді Харківського навчального округу в Центральному державному історичному архіві України в Києві, він повторюється у двох справах з приводу планів про побудову Ніжинської гімназії ${ }^{34}$, для публікації обрано повніший варіант.

У пропонованому документі автор прагне дотримуватись училищного статуту 1804 p. («Устав учебных заведений, подведомых университету») ${ }^{35}$ і поділяє освіту згідно зі статутними правилами. Загалом же Стойкович у своїх міркуваннях дотримується настанов педагогіки Просвітництва (з поєднанням навчання і фізичних вправ), і дуже відчутний вплив його освіти в Геттингені. Досить цікавими $є$ міркування вихованця німецьких університетів про дисципліну та поліційний нагляд, що спрямовує на властиві для Просвітництва думки про засоби впорядкування та контролю.

Однак думки Стойковича не слід вважати пересічними. Зрозуміло, він прагне організувати «Гімназію вищих наук», нижчий за університет заклад, але й відкритіший щодо освіти та виховання. Водночас він дуже помітно працює над доповненням згаданого офіційного статуту, внесенням до нього істотних доповнень і конкретизацією назв підручників (зважмо, все іноземних) та особливостей учительської праці.

Уже початок розробки ніжинських гімназійних документів викликав дискусії серед харківської професури, на чому мав би взоруватися заклад (вважалося, що взірцем мав стати Демидовський ліцей у Ярославлі). Як пише сам Стойкович, «мнения различны» ${ }^{36}$. Але все ж основний план склав саме Афанасій Стойкович. Треба також визнати, що запропонований Стойковичем план викликав незначні ремарки в «російських» професорів Харківського університету Тимофія Осиповського та ректора Івана Ризького 37 (переважно щодо підручників та книжок для вчителів). 
Документ дещо адаптовано під сучасну російську мову зі збереженням авторської стилістики та деяких лексичних особливостей. Окремі іноземні назви книжок та підручників не вдалось ідентифікувати чи прочитати. Вважаємо, що цей план ніжинської гімназії важлива пам'ятка педагогічної думки та історії освіти в Україні.

${ }^{1}$ Миловидов Л. Проєкти вищої школи на Чернігівщині (1760-1803рр.) // Записки Чернігівського наукового товариства. - Чернігів, 1930. - Т. 1. - С. 65-89.

${ }^{2}$ Воронов А. С. Федор Иванович Янкович де Мириево, или народные училища при императрице Екатерине Второй. - СПб., 1858. - 168 с.

${ }^{3}$ Андрияшев А. Материалы для истории учебных заведений Черниговской губернии с 1789 по 1832 г. - К., 1865. - C. 15.

${ }^{4}$ Страшнюк С. Ю. Сербське підгрунтя Харківського університету: Атанасіє Стойкович // УКРАС: Українсько-сербський збірник. - 2009. - Вип. 1 (4). - С. 14, 17.

${ }^{5}$ Багалей Д. Опыт истории Харьковского университета (по неизданным материалам). - Харьков, 1898. - T. 1 (1802-1815). - С. 506-507.

${ }^{6}$ Страшнюк С. Ю. Сербське підгрунтя Харківського університету. - С. 17-18.

${ }^{7}$ Модзалевский В. Стойкович Афанасий Иванович // Русский биографический словарь. - СПб., 1909. - Т. 19. - С. 432-435.

8 Лавровский Н. Эпизод из истории Харьковского университета (А. И. Стойкович; И. Г. Шад) // Чтения в Обществе истории и древностей российских при императорском Московском университете. $-1873 .-$ Кн. II (Смесь). - С. 1-58.

${ }^{9}$ Модзалевский В. Стойкович Афанасий Иванович. - С. 433-434.

${ }^{10}$ Багалей Д. И. Опыт истории. - С. 305-306, 670, 915.

${ }^{11}$ Кравченко В. Харківський університет у першій половині ХІХ ст. // Харківський національний університет ім. В. Н. Каразіна за 200 років / В. С. Бакіров, В. М. Духопельников, Б. П. Зайцев. - Харків: Фоліо, 2005. - С. 71.

12 Лавровский Н. Эпизод из истории Харьковского университета. - С. 34.

${ }^{13}$ Роммель К.-Д. Спогади про моє життя та мій час. - Харків, 2001. - 236 с.

14 Там само. - C. $125-128$.

15 Jakob L. H. von. Denkwürdigkeiten aus meinem Leben / Hg. von Hans-Joachim Kertscher in Zusammenarbeit mit Michael Mehlow. - Halle-Wittenberg: Universitätverlag, 2011. - 320 s.

${ }^{16}$ Цебриков Р. М. Путешествие из Петербурга в Харьков / Сост., автор вступ. статьи и комментариев В. Ю. Иващенко. - Харьков, 2013. - 236 с.

17 Лобойко И. Н. Мои воспоминания. Мои записки / Вступ. статья, подгот. текста, сост. библиогр. списка и коммент. А. И. Рейтблата. - Москва: Новое литературное обозрение, 2013. - 328 с.

${ }^{18}$ Цебриков Р. М. Путешествие из Петербурга в Харьков. - С. 89-91.

${ }^{19}$ Jakob L. H. von. Denkwürdigkeiten aus meinem Leben. - S. 183-184.

${ }^{20}$ Лобойко И. Н. Мои воспоминания. - С. 35, 37, 209.

${ }^{21}$ Там само. - С. 29.

${ }^{22}$ Багалей Д. И. Опыт истории. - С. 1035-1046.

23 Лавровский Н. Эпизод из истории Харьковского университета. - С. 38-58.

${ }^{24}$ Страшнюк C. Сербське підгрунтя Харківського університету. - С. 27-30.

${ }^{25}$ Багалей Д. И. Опыт истории. - С. 1124-1130.

${ }^{26}$ Кочубей П. А. Учреждение Гимназии высших наук в городе Нежине. Письма графа В. П. Кочубея // Русская старина. - 1870. - Сентябрь. - С. 301

${ }^{27}$ Сборник постановлений по Министерству народного просвещения. - СПб., 1904. - Т. 1: Царствование императора Александра I, 1802-1825. - С. 429.

${ }^{28}$ Центральний державний історичний архів України в місті Києві (ЦДІАК України), ф. 2162, оп. 1, спр. 63, арк. 1 і зв., 2.

${ }^{29}$ Державний архів Харківської області (ДАХО), ф. 667, оп. 283, спр. 102, арк. 13.

${ }^{30}$ Полевой П. Граф Александр Григорьевич Кушелев-Безбородко // Гимназия высших наук и лицей князя Безбородко. - СПб., 1881. - С. 173.

31 ДАХО, ф. 667, оп. 283, спр. 102, арк. 10-12.

${ }^{32}$ Багалей Д. И. Опыт истории. - С. 327.

${ }^{33}$ ЦДІАК України, ф. 2162, оп. 1, спр. 34, арк. 1-2.

${ }^{34}$ Там само, ф. 2162, оп. 1, спр. 27, арк. 12-25; спр. 34, арк. 10-36.

${ }^{35}$ Сборник постановлений по Министерству народного просвещения. - Т. 1. - С. 331-368.

${ }^{36}$ ЦДІАК України, ф. 2162, оп. 1, спр. 27, арк. 10.

37 Там само, ф. 2162, оп. 1, спр. 34, арк. 37-38, 40-44. 


\title{
Рапорт Афанасія Стойковича до Училищного комітету про складання ним плану організації навчання в Ніжині. 13 жовтня 1805 p.
}

\author{
В училищный Императорскаго Харьковского Университета Комитет \\ Профессора Афанасия Стойковича

\section{Рaпाпрт}

Совет Императорскаго Харьковского Университета поручил мне истекшего 9 сентября составить План и Штат для Гимназии в Нежине, учреждаемой благодетельством Его Сиятельства Графа Безбородка. Поспешив исполнить порученное мне, имею честь представить при сем оный План на благорассмотрение сего Комитета.

Все что только ни почитал я самонужнейшим помещено мною в сем Плане, и если Комитету покажутся некоторые в нем вещи посторонними, то таковые может оставить, а равно если в оном же Плане сыщет некоторые от обыкновения отходящие мнения, то и таковые могут по рассмотрению Комитета быть принятыми или отвергнутыми. Мне осталось только сделать одно особенное об учителях примечание; но как таковое не только к учителям сей но и других Гимназий относится, то и почитал я что довольно будет, если оное представлю Комитету не вставляя его в самый План.

Каждый учитель нами в должность определяемый, должен иметь два свойства, от коих нам никоим образом отступить невозможно: первое способность в учителе к отправлению своей должности; второе нравственность характера. Под словом способность, разумея не одно только знание науки, но и умение преподавать оную; следовательно должен он иметь искусство Дидактическое. Известно однакоже, что первое не редко бывает без другого. Что же под нравственностию характера разуметь должно, то все мы равно согласуемся. Ежели одно из свойств сих отсутствует в учителе, то он недостоин быть таковым; по причине что столь же равно, если и неболее действует на учеников нрав его и поведение как и Знание. Не оспоримо то, что при самом начале, в коем мы теперь находимся, мы не можем столь строго требовать первого, то есть, способности; следовательно в начале для нас довольно будет и того, если мы при определении всякого к месту учителя, точно уверены что для занятия оного, не найдено более способного и лучшего поведения человека. Чтобы судить о способностях определяемаго производим таковому до сего времени у нас экзамен. Я не одобряю вещей, для испытания учителей, даваемые ими чужим ученикам. Сие имеет как со стороны учителя, так и учеников некоторые неудобства; лучше же всего производить таковые испытания в самом Комитете. Что же касается до второго свойства, для сего служат аттестаты, и то, когда личное поведение учителя известно.

Мы с своей стороны должны остерегаться, чтобы часы для уроков учителям не были умножаемы, что бывает, когда учитель берется нести две должности; ибо от сего лишается он времени простирать далее познания свои в науках, и остается при том только, что им прежде было выучено. Многие часы в обучении препроводимые делают человека тупым, и следствием своим имеют механизм неприготовленного к лекциям учителя, что есть для учеников величайшим убытком. Сие и было причиною, что учителям языков в Гимназии, старался я дать только 22 часа для преподавания двух языков.

Из приложенных табелей видно, что таблица расположения часов в Гимназии мною не сочинена, но таковое расположение часов следует из Таблицы $\mathrm{C}$, из которой легчайше может быть составлено. При составлении таковой и всякой подобной Таблицы сочинитель должен наблюдать двойное: первое: чтобы до обеда преподаваемы были науки, более прочих напряжения ума требующия, по причине, что поутру силы душевные действуют легче чем по полудни. Второе, расположить так материю, чтобы не все одне и те же способности души были в действии, но чтобы науки, ум или память или же вообразительную силу требующие, преподаваемы были одна за другою попеременно. В институтах, как то в Нежине предполагается, должны науки переменяемы быть с механическими и гимнастическими упражнениями.

Харьков, 13 октября 1805

Центральний державний історичний архів Украӥни в місті Києві (ЦДІАК Украӥни), ф. 1262, on. 1, спр. 34, арк. 10 i зв. 11. 


\title{
План навчання в Гімназії вищих наук Безбородька в Ніжині професора Афанасія Стойковича (Жовтень 1805 р.)
}

\author{
ПЛАН
}

\author{
Образования Гимназии вышних наук в Нежине
}

1. Гимназия учреждаемая в Нежине под именем Гимназии Безбородка вышних наук учреждается тем намерением, чтобы дети, особливо неимущих дворян и другого состояния людей, лишающиися по скудости своей достаточных способов к образованию себя, находили в ней обильные средства к приобретению познаний в науках, языках и искусствах, нужных не только для всякого рода государственной службы, но и для других состояния людей.

2. По своему уже наименованию и по намерению ея основателя Его Сиятельства Графа Безбородка разнствует она уже от прочих губернских гимназий. В ней кроме предметов в тех гимназиях преподаваемых должны еще быть обучаемы и многие другие науки, не означенныя в Гимназиях. Сверх того по намерению основателя ея должны в ней содержаться на ея иждивении около 60 неимущих питомцев ${ }^{1}$.

3. Гимназия разделяется на три отделения

а. Приходское Училише

b. Уездное Училище

c. Собственно так называемая Гимназия ${ }^{2}$.

4. В целой гимназии имеется 15 учителей, из того числа в приходском Училище один, а в Уездном два учителя.

5. В собственно так называемой Гимназии имеется 12 учителей, из коих шесть учителей наук именуются Старшими, шесть же учителей языков и свободных искусств и рисования, младшими.

6. Старшие Учители суть:

1. Философии, изящных наук и прав естественного и отчественного.

2. Математики, физики и начал химии.

3. Истории, географии и статистики всеобщим и Российского государства.

4. Естественной истории, технологии сельского и лесного хозяйства.

5. Наук коммерческих и политической экономии.

6. Антропологии. Хирургии и скотолечения.

7. Младшие учители.

1. Гражданской архитектуры, практической механики, практической геометрии и рисования.

2. Латинского и немецкого языков и литературы их.

3. Французского и италианского языков и литературы их.

4. Греческаго языка древнего и нового.

5. Музыки.

6. Танцования и прочих гимнастических упражнений.

8. Я разделяю План на следующие статьи

I. Преподавание учебных предметов.

II. Пособия к преподаванию оных.

III. Побудительные к наукам пособия.

IV. Дисциплина.

V. Пенсионеры.

VI. Примерный штат всей Гимназии.

Преподавание учебных предметов.

9. В Приходском училище обучает один учитель всем предметам положенным по $\S 120$ Устава учебных заведений подведомых университетам ${ }^{3}$. Я присоединяю здесь и чтение на других языках, особенно же чтение рукописное и начала российской грамматики (по крайней мере механическим образом склонять и спрягать), начала каллиграфии, из географии первые понятия на пример: что такое горы, долины, города, места, селения, реки, ручьи, 
государства, республики и прочее. Из натуральной истории и из общежития некоторые краткие повествования для изощрения ума.

10. Училище приходское разделяю я на два отделения, и курс в оном продолжается один год (§ 131. Устава учебных заведений $)^{4}$.

Учитель в сем училище ежедневно преподает учение свое 5 часов, следовательно 30 часов в неделю. Примерная оном учению таблица под буквою $\underline{\mathrm{A}}$ при сем прилагается.

11. В Уездном училище предметы преподаются по $85 \S$ Устава учебных заведений, к которым присоединяю я еще и некоторые другие.

12. Учение в уездном училище, имея два класса, продолжается следовательно и два года.

13. В первом годе преподаются юношеству Закон Божий, Священная история, должности человека и гражданина, российская и немецкая грамматики (§ 85. Устава учебных заведений), чистое правописание, география и история российская, арифметика, рисование, чтение и писание латинского и немецкого языков.

14. Во втором классе продолжаются недокончанные предметы первого класса; преподаются катехизис и изъяснение Евангелия, всеобщая история и география, начала физики и естественной истории, первые основания Эмпирической психологии, геометрия, российская и греческая грамматики. Латинской и немецкой языки продолжаются и преподаются начала французского языка ${ }^{5}$.

15. В уездном училище каждый учитель продолжает свое учение 30 часов в неделю.

Первой Учитель обучает:

Закону Божию в первом классе

Должностям человека и гражданина

Российской и греческой грамматике

Чистописанию и правописанию

Латинскому и немецкому языкам во втором классе

Российской грамматике и правописанию

Катехизису и изъяснению Евангелия

Латинскому и немецкому языкам

Вторый учитель обучает: в первом классе

Арифметике

Географии

во втором классе

Всеобщей истории и географии 3 часа

Началам физики и естественной истории

Началам технологии

/итого 30 часов

Началам геометрии

Французскому языку

$\begin{array}{cl}6 \\ 4 \\ \\ 6 \\ 4 \\ 3 \\ 3 \\ 4 \\ \text { /итого } & 30 \text { часов }\end{array}$

Из сих двух учителей один обучает в неделю 4 часа рисованию, за что получает особенное жалованье. Примерной План обучения прилагается под лит: $\underline{\mathrm{B}}$.

16. В Гимназии существует пять классов, следовательно и учение продолжается пять лет; но можно и меньше, ежели кто из учащихся не похочет выслушать всех предметов. Пятый курс преподается только для тех, кои не желая продолжать наук в университете, оканчивают учение свое в гимназии ${ }^{6}$.

\section{А. Учение по классам и предметам.}

17. В каждом классе учение преподается в неделю 32 часа $^{7}$ т. е. в понедельник, вторник, четвертом и пятом 4 часа по утру, а с 2 часа после обеда; в среду и субботу только прежде обеда 4 часа, в которые дни после обеда учители рисования обучают рисовальному искусству.

18. Старшие учители преподают свои лекции по 18 часов в неделю. Учители же языков латинского, немецкого, французского и италианского употребляют по 11 часов в неделю 
на каждой язык; которое время достаточно по тому, что первые три языка, уже в уездном училище начались преподаваться, а италианский хотя в уездном училище и не преподается, но он весьма сходствует с латинским, следовательно и выучить его не затруднительно ${ }^{8}$.

Учитель гражданской архитектуры ${ }^{9}$ каждую неделю обучает 8 часов, кроме рисования, которому обучает он в среду и субботу в послеобеденное время, в каждый из сих дней по 3 часа; т. е. первый класс от 1-го до 1/2. третьего, второй от 1/2. третьего до 4-го в среду; а в субботу третий класс от 1 -го до $1 \frac{1}{2}$. третьего; четвертый класс от 1/2. третьего до 4 часа.

Музыка и гимнастическия искуства могут преподаваемы быть по окончании учебных часов (по § 20 Устава учебных заведений) ${ }^{10}$ что же принадлежит до греческого языка ${ }^{11}$, то оном можно будет обучать по средам и субботам по полудни, по причине что только одна четвертая доля учеников всегда занята бывает рисованием, прочие же три доли остаются праздными.

19. В первом классе преподаются.

1. Эмпирическая психология, логика, и всеобщая грамматика.

2. Чистая математика.

3. Вспомогательные историческия науки Энциклопедическим образом / Historische Haelfts-Wissenschaft ${ }^{12}$ / и новая география.

4. Естественная история, исключая ботанику.

5. История и наука коммерции и латинской, немецкой, французской и италианской языки.

20. Во втором классе эстетика; поэзия; риторика; продолжается чистая математика и начинается физика вместе с прикладною математикою; древняя история, с изъяснениями при всяком оной периоду древней географии, мифологии и древностей; ботаника; права коммерческое и морское и продолжение языков.

21. В третьем классе нравственная моральная философия, естественное и народное права; продолжается физика вместе с прикладною математикою, новая история и статистика, технология, бухгалтерия, познание фабрик и товаров, и продолжаются языки.

22. В четвертом классе всеобщее государственное и отечественное право, история, география и статистика российского государства; продолжаются технология, политическая экономия, преподаются анатомия и физиология, и оканчиваются вышеупомянутые языки.

23. В пятом классе химия, сельское и лесное хозяйство, и садоводство, полиция, хирургия, скотолечение, гражданская архитектура, механика и практическая геометрия ${ }^{13}$.

\section{В. Учение по учителям}

24. А. Учитель философии преподает
a) психологию эмпирическую
b) логику и всеобщую грамматику $\}$
c) естетику, поезію риторику
d) нравственную философию, естественное и народно е права
е) всеобщее государственное и отечественное права

\section{5. В. Учитель физики и математики}
a) чистую математику
b) физику вместе с прикладною математикою
d) начала химии

$\begin{array}{cl}\text { в I клас. } & 4 \text { часа } \\ \text { II } & 4 \\ & \\ \text { III } & 4 \\ \text { IV } & 6 \\ \text { /итого } & 18 \text { часов }\end{array}$

\section{6. С. Учитель истории}

$\begin{array}{cl}\text { I } & 6 \\ \text { II } & 4 \\ \text { III } & 4 \\ \text { V } & 4 \\ \text { /итого } & 18 \text { ч. }\end{array}$
a) вспомогательные исторические науки
и новую географию
b) древнюю историю и географию
c) мифологию и древности
d) новую историю и статистику общие
c) историю, география и статистика российского государства

$\begin{array}{ll}\text { I } & 4 \\ \text { II } & 4 \\ \text { III } & 6 \\ \text { IV } & 4\end{array}$


27. D. Учитель естественной истории
a) естественную историю
b) ботанику
c) технологию
d) сельское и лесное хозяйства и садоводство

28. Е. Учитель коммерческих наук
a) историю и науку коммерции
b) право коммерческое и морское
c) бухгалтерию
d) познание фабрик и товаров $\}$
е) сельское и лесное хозяйства и садоводство
f) полицию

29. F. Учитель антропологии и скотолечения
a) анатомию антропологическим образом
b) физиологию
c) хирургию
d) скотолечение $\}$

$\begin{array}{cl}\text { I } & 4 \\ \text { II } & 4 \\ \left.\begin{array}{ll}\text { III } & 3 \\ \text { IV } & 3\end{array}\right\} & 6 \\ \text { V } & 4 \\ \text { /итого } & 18 \text { ч. }\end{array}$

30. G. Учитель гражданской архитектуры
a) архитектуру
b) практическую механику
c) практическую геометрию
d) рисование

31. Н. Учитель латинскаго и немецкого языков. (по § 25 и 26 Устава учебных заведений) преподавать по 11 часов в неделю, т.е.

а) латинскому языку

\begin{tabular}{|c|c|}
\hline I & 4 \\
\hline II & 4 \\
\hline III 3 & 4 \\
\hline IV & \\
\hline $\mathrm{V}$ & \\
\hline /итого & \\
\hline
\end{tabular}

$\begin{array}{cl}\text { IV } & 6 \\ \text { V } & 12 \\ \text { /итого } & 18 \text { ч. }\end{array}$

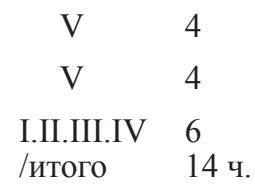

b) Немецкому языку

$\begin{array}{cl}\text { I } & 3 \\ \text { II } & 3 \\ \text { III } & 3 \\ \text { IV } & 2 \\ \text { /итого } & 11 \text { ч. } \\ \text { I класс } & 6 \text { час } \\ \text { II } & 3 \\ \text { III } & 3 \\ \text { IV } & 3 \\ \text { /итого } & 11 \text { часов }\end{array}$

32. F. Учитель Французскаго и Италианского языков. (по § 25 и 26 Устава учебных заведений), т.е.
a) Французскому
b) Италианскому

$\begin{array}{cl}\text { I } & 3 \\ \text { II } & 3 \\ \text { III } & 3 \\ \text { IV } & 2 \\ \text { /итого } & 11 \text { часов } \\ \text { I } & 2 \\ \text { II } & 3 \\ \text { III } & 2 \\ \text { IV } & 4 \\ \text { /итого } & 11 \text { часов }\end{array}$


33. К. Учитель Греческаго языка.

34. L. Учитель музыки.

35. М. Учитель Танцевания и Гимнастических упражнений.

Предметы сих трех полезных учителей сами по себе известны.

Табель расположения по классам и предметам, учителям и часам прилагается здесь под буквою $\underline{\mathrm{C}}$.

\section{II}

36. Пособия к преподаванию наук: каковые суть:

А. Книги учебные, краткие для учеников, и для учителя обширнейшие, из коих мог бы он почерпнуть дальнейшие познания.

В. Библиотека.

С. Другие собрания нужные во всяком училище.

А. Книги учебныя, краткия для учеников, и для учителя обширнейшия, из коих мог бы он почерпнуть дальнейшия познания.

37. а) Чтобы сделать совершенным план обучения должно чтобы и книги, по коим оное будет преподаваемо, равномерно были в нем означены.

Книг для Приходского училища нужных, на российском языке имеется уже довольно, и предполагаемому в нем обучению достаточно соответствующих. Желательно бы мне было, чтобы для начал арифметики переведена была на российский язык книга г-на Бирмана Lehrbuch für den ersten Unterricht im Kopf und schriftlichen Rechnen J.A. Birmann. Dritte Auflage, $1803^{14}$.

А для изощрения ума нужно чтобы для детей имелась такая книга, в которой бы преподавались только краткие поветствования о чувственных вещах, разные притчи, примерные поступки и проч. Таковая книга имеется на немецком языке сочинения для Лейбцигских свободных училищ... ${ }^{15}$. Поелику я в сем же самом классе и каллиграфию полагаю, то бы весьма хорошо было, если бы для сего предмета сделано было собрание примеров, которые дети, переписывая, могли бы тем изощрять свой ум.

38. b) Для Уездного Училища так же имеются на российском языке все нужные книги, но которые однако же не все соответствуют своему намерению. Для первого класса Уездного училища книги имеются. Во втором классе того же училища не имеется книги 1. для Всеобщей истории и Географии. 2. для Естественной истории. 3. для Начал технологии. Для Всемирной истории учитель может употреблять г-на Шлецера (Vorbereitung zu Weltgeschichte für Kinder) ${ }^{16}$ для Географии. При Физике учитель может советоваться с ... ${ }^{17}$ для Естественной истории и Технологии Aufzug zur der Naturgeschichte und zur Technologie von Funke ${ }^{18}$, для Немецкого языка Weisung zur kleine... ${ }^{19}$.

39. с) Для Гимназии предложу я здесь книги учителям.

40. 1) Учитель Философии мог бы перевесть книгу немецкую Lehrbuch der Philosophie von...Yunl1 ${ }^{20} / /$ в которой есть Психология эмпирическая, Логика, Естетика, Моральная философия, Естественное, Народное и Всеобщее права; но нам книга сия не велика, то и мог бы он преподавать по оной и свое учение. Для Поэзии, Реторики, Всеобщей Грамматики и Отечественного права нужно бы было сочинить не большия книжки, учитель философии мог бы употреблять учебныя книги профессора Якоба, Федера, Тителя и Кизеветтера ${ }^{21}$. Поелику тот же учитель должен преподавать и Российскую литературу, то при сочинении книг для поэзии и реторики нужно бы было дать историческое понятие о российских писателях, т.е. краткое описание их жизни, сочинений и доброты сих последних. А нам все оные книги не можно иметь в Гимназии, то нужно бы было сделать Хрестоматию, подобную Хрестоматии немецкой г-на Ешенбурга 22.

40. 2) Учитель Математики для себя мог бы употреблять курсы математики Осиповского, Ксетнера и Безу ${ }^{23}$, из коих два последние и имеются уже переведенными на российской язык, но как все оные математические курсы чрез меру пространны, чтобы по оным можно было преподавать в Гимназии сей учение, то для сего желательно бы было чтобы переведена была книга (... $)^{24}$, состоящая из небольших двух томах. Для Физики нужно бы было перевести $(\ldots)^{25}$. Учитель может пользоваться физикою на российском языке переведенною Эркслебена, Бриссона и Гиларевского ${ }^{26}$. А чтобы иметь понятие о динамической Системе равномер, может употреблять он немецкие книги Фишера ${ }^{27}$ и 
Гре...ена ${ }^{28}$. Для Химии довольно находится французских и немецких книг. Для учеников есть книжки Имгофа ${ }^{29}$, Греена и Гиртанера ${ }^{30}$; для учителя Лавуазье, Фуркруа ${ }^{31}$, Греен, Тромс...дор $\phi^{32}$ и проч.

41. 3) Учитель Истории для вспомогательных наук должен бы сделать выписки из Гаттереровых сочинений ${ }^{33}$ при новой Географии советоваться с Gaspary... ${ }^{34}$ с Екстрактом Гутрия ${ }^{35}$, поелику после издания Географии на российском языке ${ }^{36}$ многия произошли уже в Европе. Для Древней истории имеется на российском языке хорошая книга 1-й том Истории изданной для Народных Училищ ${ }^{37}$; но учитель может читать Миллота и Роллена ${ }^{38}$. Для Мифологии и Древностей не худо бы было употребить книгу г-на Ешебурга Handbuch der klassischen Literatur ${ }^{39}$ где кроме мифологии и древностей находится обозрение литературы Греческой и Латинской. Древней Географии для училищ на российском языке совсем не имеется. Желал бы я чтобы переведена была небольшая книжка ...zur alten Geographie ${ }^{40}$.

Учитель может употреблять Древнюю Географию Маннерта ${ }^{41}$ или еще лучше Географию Герена, Геттингенскаго профессора ${ }^{42}$. Новая История на российском языке состоящая в двух томах, для Гимназии весьма пригодна ${ }^{43}$. Учитель может читать Миллота, Шрека, Ремера $^{44}$. Статистики не имеется на российском языке, но и на немецком нет такой, которая бы краткостью своею соответствовала гимназическому учению. Можно бы сделать Экстракт из Статистики г-на Меузеля ${ }^{45}$, а учитель сам мог бы употреблять того же Меузеля, Спренгеля и Лакроа ${ }^{46}$.

42. 4) Учитель Естественной Истории имеет на российском языке для преподавания две краткие весьма хорошие книги, из которых одна издана для Народных Училищ ${ }^{47}$. Сам же он имеет на российском же языке довольное число Книг для чтения. Для Ботаники может он употреблять Батша ${ }^{48}$ или Вильденова руководства к познанию ботаники ${ }^{49}$. Для обозрения Естественной истории нужно бы было перевесть Funke... ${ }^{50}$ :

a.)
b.)
c.)

Для Технологии довольно находится предметов для учителя в вышесказанной г-на Функа книге. Учитель также может употреблять Бекманна ${ }^{52}$, Шпренгеля ${ }^{53}$ и Бродгагена, для учеников же нужно бы было перевесть... ${ }^{4}$. Для Сельского хозяйства и скотоводства учитель может употреблять Гермерсгаузена ${ }^{55}$ ученую книгу г-на Миттерпахера Elementa Rei Rusticae ${ }^{56}$. Для учеников можно бы было сделать Экстракт из книги г-на Бекманна ${ }^{57}$. Для Лесного хозяйства можно сделать выписки из Вальтера и Бургсдорфа ${ }^{58}$.

43. 5) Учитель Коммерческих наук для истории может употреблять книгу изданную для сего в Вене директором Коммерческаго училища ${ }^{59}$. Наука Коммерции имеется от Геттингенскаго профессора Бекманна Anleitung zur Handlung Wissenschaft ${ }^{60}$ о правах Коммерческих писал между прочим Музеус Einnführung zur Handlung Recht ${ }^{61}$. При всех сих Коммерческих науках учитель может употреблять...62. Имеется также и на российском языке изданная Коммерции книги г-ном Геймом профессором Московскаго университета ${ }^{63}$. Политическую Экономию может преподавать по Сарториусу ${ }^{64}$, а сим очень много может почерпнуть из новой изданной книги Якоба, профессора галльского ${ }^{65}$, полицию по Юнгу ${ }^{66}$ и Розигу.

44. 6) Учитель Медицинских наук (Анатомии и Физиологии Антропологии) может преподавать по книге Лодера ${ }^{67}$ хирургию. Скотолечение, между прочим, по Виллету ${ }^{68}$, переведенную с многими примечаниями с французскаго на немецкий язык.

45. 7) Учитель Архитектуры имеет на российском языке маленькую книгу для народных училищ изданную ${ }^{69}$. Учитель может пользоваться Гюнтером... ${ }^{70}$. Для механики находится на российском языке только известно две книжки ${ }^{71}$. Для учителя полезна будет книга Theatrum Machinarium ${ }^{72}$ и.... ${ }^{73}$ Для практической Геометрии есть ли особенно изданная книга, мне не известно, но она во всех курсах математики находится. Учителю довольно будет иметь одну книгу Майера Mayers Gründlicher und ausführlicher Unterricht zu practischen Geometrie ${ }^{74}$.

46. 8) Учитель Латинского и Немецкого языка имеет для перваго Грамматики Бредеровы $^{75}$, малую для учеников, а большую для себя. Хрестоматии же меньшую изданную Гедином ${ }^{76}$ и большую Шомпрером ${ }^{77}$ для немецкого языка книги Аделунговы весьма известны ${ }^{78}$. Для латинского языка сочинил также г-н профессор нашего университета Де Балю: Таблицы и Словарь коренных речений ${ }^{79}$. 
47. 9) Учитель Французского и Италианского языков. Для обоих сих языков имеются практическия Грамматики Майдингера ${ }^{80}$, которыя писаны для немцев, следовательно должно бы было преладить оныя и на российский язык. Впрочем Грамматики французския Вальи, Ресто ${ }^{81}$ и проч. могут также быть употреблены; Италианская Венерона и Ягемана довольно известны. Хрестоматия французская очень хороша и издана в Берлине в 1800 -м году ${ }^{83}$. Из которых первая французских прозаиков, а вторая поэтов в себе содержат. Хрестоматия италианская имеется сочинения Ягемана ${ }^{84}$.

\section{В. Библиотека}

48. Что для Нежинской гимназии нужна Библиотека, то не оспоримо. Но здесь спрашивается какая именно Библиотека долженствует быть в оной и вообще во всех гимназиях. Все зависит от удобоупотребительности самых книг. Книги, которыя только для великолепия покупаются, и в публичных других библиотеках могут занимать место, суть весьма хороши и добрые, но не полезные для Гимназии. Цена Гимназической Библиотеки не зависит от множества и редкости книг, как то в других библиотеках, но от удобоупотребительности и соответствования их предназначаемой их цели. В сем последнем случаю чтобы точно таковыя, а не другия книги покупались для Гимназической Библиотеки можно будет положиться разве только на ученого и просвещенного учителя, которому бы литература была известна; вещь весьма редкая. Книги долженствующие быть в Библиотеке разделяю я на три класса.

a) Книги о Педагогике и Дидактике, как то например Нимайера, Лойка, Руссо, Резевица, Базедова, Кампе, Гайзингера, Фирталера ${ }^{85}$ и проч., из которых учитель может почерпнуть познание, каким образом преподавать науки, и научиться между тем самой труднейшей части педагогики, т.е. всякому возрасту лет свойственной образ преподавания и обхождения с учениками.

b) Вспомагательные для учителей книги тех наук, кои преподаются в Гимназии. Часть сия есть самая важнейшая и для оной назначены уже мною книги как то выше сего показано.

с) Книги для чтения учеников для того чтобы юношество, читать или упражняться желающее, имело таковые для образования ума своего и сердца, и не читало б всякого рода книги в руки им попадающиеся, не умея сделать оным выбора; к сему классу принадлежат описания путешествий, избраннейшие лучшие романы, лучшие театральныя пиесы, книги для чтения определенные как то: Детской друг .... ${ }^{86}$ все книги г-на Кампе, Андре, Бехштайна ${ }^{87}$ и Салцманна ${ }^{88}$ и др.

\section{С. Другия собрания по всяком училище нужныя}

49. Под именем других сих собраний разумею я пособия, посредством которых все чему учитель не учит представляемо бывает ученикам чувственно $(\ldots)^{89} \ldots$ таковые суть.

а) Собрания естественных произведений для Натуральной истории, Ботаники и Химии. Учитель может многия произведения природы сам собирать с учениками вместе; что однако же может служить одним только дополнением, но целое собрание все должно быть куплено. Собрание минералов можно купить дешевою ценою в Венгрии в Шемнице и Кремнице; в Саксонии в Фрейбурге в Моравии в Брине. Для Зоологии можно иметь хорошия изображения иллюминованных всех вообще животных как то находится при Системе линнеевой изданной Миллером ${ }^{90}$. В Гале можно получить до двух сот вылитых животных весьма дешевою ценою.

b) Модели для механики, сельского хозяйства, смешанной математики и проч.

c) Инструменты физическия, математическия и хирургическия, каковое собрание двух первых можно иметь в Лейбциге у доктора Таубера, и в Берлине в Каттелевой инструментальной лавке.

d) Собрание штофных материй, для познания произведений фабрик, которое, как кажется, может учитель сделать и в самом Нежине. Собиратель материй мог бы воспользоваться книгою... $1788^{91}$.

е) Ландкарты как для Новой, так и для Древней и средней географии. Для Новой самые лучшие суть те, кои выходят в...92 в Веймаре; для Древней географии находятся ландкарты изданныя Фабрием, Гинвилем, Маннертом и Келером. Для Средней же по различным 
переселениям народов г-м Крузе. К ландкартам также можно причислить исторические таблицы, каковы суть того же Крузе, Бредова, Ремера и проч.

f) Гравированные оригиналы для рисования, Гражданской архитектуры и Анатомии можно купить в Англии или Лейбциге.

III.

Побудительныя к наукам пособия

А. Испытание учеников ${ }^{93}$.

50. Учащие и учащиеся должны в известное время иметь какия ни есть побуждения к наукам, из которых преимущественнейшее есть испытание. В отношении к учителю: имеет от всегда случай показать, что преподавал учение свое с пользою. А ежели делает он испытание свое торжественно, то побуждается еще упражнением себя в улучшении методы. Преподавание предметов изыскивает лучшие способы обучения; поелику присутствующие лучше о сем могут рассуждать, нежели обучающиеся у него ученики. Со стороны же учеников ожидают они в оный день, или одобрения себе, или тьму совсем противного, что самое и побуждает их всегда к прилежанию. Для достижения сей цели долженствуют быть торжественные испытания не так как обыкновенно оные происходятся т. е. должно чтобы со стороны учителей не было употреблено никаких обманов, следовательно никакого бы особенно к экзамену приготовления. Ибо не в том обязаны ученики отдать отчет что ими в последних днях пред экзаменом наизусть выучено, но в том прилежны ли были чрез все время продолжения курса. Посему весьма не похвально и худо, если ученикам на перед задаются от учителей вопросы, а в равной степени не похвально и то если только одни лучше успевшие из учеников испытываются на экзамене. Испытание будучи общее должно и всем ученикам быть производимо, не исключая никого поелику учащийся испытывается, то учитель и не должен к тому примешивать своих ответов. В испытаниях таким образом порядочно устроенных можно видеть как развиваются душевные способности учеников, как то вообразительная сила, остроумие, присутствие духа и готовность к ответам. Испытания суть для учеников вели, придающие деятельности их более сил, ибо пред публикой показать себя не токмо на молодых но и на учеников взрослых лет много действует. Говоря о торжественных экзаменах не следует исключить и приватных самими учителями производимых; но тем более побуждают учеников, чем более ожидают они от сего себе награждений и видят в том собственную свою пользу.

\section{В. Цензура прилежания ${ }^{94}$}

51. Второе поощрение к прилежности к наукам есть цензура прилежания. Оно, действуя на учителя, действует равно и на учеников: на учителя, поелику он старается содержать учеников в непрестанной внимательности; на учеников же, потому что они в известные времена ожидают о себе выгодного или невыгодного в пользу свою заключения учителей своих и родственников. Спрашивается только здесь, какого имянно рода должна быть публикация такой цензуры. Она может быть сообщена только одним ученикам и их родственникам, но не посторонным людям и целой публике. Первым потому, что ученики, когда цензура окажется в пользу их, ожидают от них себе уважения, если же не в пользу, то тщится заслужить оное; посторонним же лицам и целой публике не нужна публикация, потому что сие было бы некоторым родом несправедливости для не успевших учеников, и для родителей их большею печалью. В прилежных же учениках рождает публика некий род суеты. Чрез что два самые нежнейшие чувствования притупляются, в первых стыд, а во вторых скромность. Одним только злодеям читаются их приговоры публично: для семо самого и учреждена классификация в Уставе учебных заведений в $§$ от 60 до 64-го ${ }^{95}$.

\section{С. Повышения в классах}

52. Каждый человек тщится между равными ему преимуществовать, у детей же присоединяется к желанию сему еще и другое желание новости и перемены. Для того весьма благоразумно положено в Уставе чтобы каждый курс продолжался только один год и так ежегодно учеников чрез новость и перемену предметов получает новые силы к успехам, причем предполагаю я, что отставший должен оставаться и на другий курс в том же клас- 
се, что самое действует сильно как на примерных так равно и на не примерных. День перемещения из класса в класс должен быть днем торжественным для Гимназии. Перемещение имеет быть по прилежанию учащихся, а не по другим причинам, и следовательно на оное поведение учеников не должно иметь большого влияния, по причине что сие имеет особенные свои награждения и наказания.

\section{D. Премии и награждения}

53. Награждения должны быть весьма простые; художественные наружные отличия на пример: посредством лент или каких постыдных Знаков кажутся мне достойными отвержения. Они суть игрушки, могущие терпимы быть в одних только низших училищах. В Гимназию же поступают ученики с некоторыми уже познаниями нравственности. И так как во всякой Гимназии есть классы наук и как по предположению моему во всяком классе должны быть классы прилежания, так во всяком же классе должны быть и классы нравственности; и каждый ученик должен ведать, в котором классе нравственности его считают. В училищах воспитываются дети для общественной жизни, в которой одна только нравственность может им дать существенную цену; следовательно они должны в молодых летах приучатся иметь высокое понятие о нравственности и в том полагать первую свою цену.

\section{IV.}

\section{Дисциплина}

54. До сего говорили мы только о науках, но важнейшее дело в училищах, есть сохранение и умножение нравственности. Наружное образование вида учеников не есть дело учителя, которое в училищах должно быть отрицательно (negative), положительно же (positive) должно быть только в институтах воспитательных. Но моральное образование учеников не должно оставатся в пренебрежении в училищах и сему весьма много может способствовать изъясненное в предидущей статьи награждение. И так во всяком случае учители обязаны возбуждать в учениках чувства нравственности морали и закона, и не только в училище, но и вне они имеют прилагать свое старание, узнать поведение учеников. К такому содержанию и сохранению нравственности, кроме Закона Божия, должностей христианских и гражданских, должна Гимназия иметь особенные правила весьма ясные (precite) ${ }^{96}$, точно определенные и в небольшем числе, которыя всякому в Гимназию вступающему должны быть прочтены в определенные времена, на пример при начале полугодичных курсов, следовательно по два раза в в год публикованы. Таковые училищные правила будут относится к нравственному моральному поведению и прилежанию учеников и должны в себе содержать все возможные случаи, могущие только произойти в Гимназии. Следствием вышеизъясненных правил есть дисциплина, разумея награждения исполняющим и наказания не исполняющим оные. Чем следствия сии натуральнее, тем лучше. Весьма бы не к стати было вопросить здесь должные существовать в Гимназии награждения и наказания? Человек должен быть воспитан в училище точно так, как и вне оного; ибо из училища прямо вступает он в жизнь общественную; дальнейшее же исследование сего нежнейшего и важнейшего предмета сюда не принадлежит: оно предоствлено тем, коим вверено попечение воспитания сынов отечеству.

V.

\section{$\underline{\mathrm{O} \text { пенсионерах }}$}

55. Поелику мысль благотворителя и основателя Нежинской гимназии не ограничивается только наставлением юношества, но простирается и на самое его воспитание, то в следствие предложения Господина Попечителя сего Университета графа Северина Осиповича Потоцкого, последовавшего от 21 дня августа сего 1805 года и предполагается учредить в оной Гимназии пенсион, в котором бы от процентов получаемых с капитала благотворителем дарованного в пользу сего училища были содержимы восемдесят неимущих питомцов $^{97}$, Подробное же постановление о сем предмете тогда можно будет сделать, когда 
откроется самая Гимназия. Я представлю здесь только некоторые идеи, могущие послужить с пользою при начертании положения о пенсионерах. Я разделяю оные на три статьи.
А. о принятии пенсионеров.
В. особенные недостатки таковых заведений и средства к улучшению оных.
С. присмотр и полиция.

\section{А. О принятии пенсионеров.}

56. Просвещенной основатель Гимназии не то имел в предмете, чтобы оной собрать только 60 питомцев, и дать им воспитание, но чтобы принимались в Гимназию таковые, кои при всех счастливых талантах и деятельности своей лишаются способов к своему образованию. Сие должно быть поставлено непреложным правилом при принятии питомцев. Я предполагаю, что принятие пенсионеров завсегда зависет будет от фамилии основателя, могущей наилучше судить о достоинстве того, кому делает она благодеяние; и ежели и сие не будет, то по меньшей мере право о представлении кого из приему остается всегда при фамилии. Но как и при том и другом случае должен быть Администратор; то должность его будет не принимать:

а. Только по одной рекомендации, по своей прихоти, и по связям кои он имеет, но ниже.

b. Смотря только на бедность и сиротство.

Следовательно правилом принятия будет 1. Хорошее поведение и прилежание. 2. Скудость, ежели принятие не утвердится на сем основании, то весьма часто недостойные облагодетельствены будут без всякой государству пользы, между тем как счастливый талант остается без помощи, но и теряется для государственной службы.

\section{В. Обыкновенные недостатки таковых заведений и средства к улучшению оных}

таковые суть:

57. а) Всякое зло распространяется более в таковых заведениях, и при такой тесноте живущих вместе бывает переимчево. Смешение столь многого числа в одном месте молодых людей, различествующих между собою возврастом, душевными и телесными дарованиями, сопряжено для многих с опасностью и искушением, от которых им не легко можно избавиться.

b) Все благодетельные влияния при домашнем воспитании бываемые не имеют здесь места, следовательно трудно доставить воспитывающимся в Гимназии гибкость и мягкость характера, тонкость и вежливость нравов.

с) Единообразие в доме таковом, даже и до самых забав в нем быть долженствующих, делает человека застенчевым, меланхоликом а часто на целую жизнь склонным к скуке.

Ad. a) Первой недостаток если не истребить по крайней мере уменьшить можно чрез умножение прилежания и тродолюбия в институте, и чрез строгий присмотр на нравственность. Что касается до прилежания, то оное должно быть всеми мерами возбуждено. Всякое средство не могущее только вредить здоровью, должно быть на сей конец употреблено. Следовательно не худо было бы завесть приличные, к состоянию благородного человека не предосудительные, ремесла как то: токарное искусство, ваяние и проч. Что же принадлежит до нравственности, то самое сие занятие предохраняет воспитанников от всякого покушения на зло. Должность же Директора в особенности будет возбудить в них чувствования истинного изящного и благого. Он должен им всегда внушать, в чем именно состоит истинное достоинство всякого человека, для чего как сам он, так равно и сотрудники его должны стараться склонить нравы учеников к чувству благородства, и действовать чрез лучших из них на худших. Для достижения которой цели необходимо нужно исключить без изъятия всякого, на поведение которого всуе истощены были все средства исправления.

Ad. b) В самом деле второго сего неудобства невозможно совсем избегнуть, но предполагая, что при учениках, как ниже сказано будет, не только для одного присмотра, но и для житья с ними, будут находиться три или четыре надзирателя, предполагаемые мною из учителей, то ученики и учители их с своими фамилиями находясь всегда вместе будут 
жить как бы в одном семействе. Директор не упустит из виду сколько возможно, будет знакомить их с лучшими домами и доставлять им в оные вход.

Ad. c) В разсуждении сего третьего пункта известно всем воспитателям, что чем дети более чувствуют внутреннего в себе удовольствия, тем более они склоннее бывают к доброму. Почему и следует в них всегда возбуждать удовольствия сего рода, средством же сему могут служить содержание всегдашней прилежности в институте необходимо нужно ввести некоторую разнообразность в жизни, чего достигнуть можно чрез торжествования известных в училище определенных на то дней, чрез испытания, чрез приватныя задаваемыя им работы переменяемы с удовольствиями. Так же должны быть учреждены в институте различные телесные игры, упражнения гимнастические, внушения истинных удовольствий природы во всякое время года, купания в летние дни, небольшие путешествия пешком, музыка, танцование, по вечерам в праздничные дни домашние приготовленные к тому разговоры, механические работы, игры содружественные, изучение мест из авторов которые должны они декламировать, маленькие физические опыты и проч.

\section{С. Присмотр и полиция}

58. а) Присмотр:

Как дети быв еще малолетными, то и присмотр за ними долженствует быть строгий. Для 80 человек не только одного, но и двух инспекторов недовольно. Я полагаю в Институте одного Директора и четверых инспекторов. Директор, живучи сам при Институте, часто чрез день времени их посещает и каждый из инспекторов имея под ведением своим по 20 детей никогда даже и при самых их удовольствиях до того времени, пока они не лягут спать их из глаз не выпускать, разве то время, в которое обучаются они в классах. Надзиратели равномерно могут с ними повторять уроки, следовательно сии последние долженствуют быть такие, которые и сами получили уже хорошее воспитание, и чрез то самое могут внушить к себе от учеников уважение. Они по предположению моему не токмо будут надзирателями, но вместе и сожителями учеников; для чего лучше всего было бы употребить в сии должности помещенных в Гимназии учителей. А чтобы над учениками поставить старших из учеников, то здесь сие совсем не к стать. Таковое надзирательство можно только употребить при университетах, где юношество находится уже в возрасших летах, но и таковые только могут быть поставлены смотрителями другими, кои имеют неоспоримые преимущества пред товарищами своими в прилежании и нравственности, такие преимущества которые не сокрыты и от самых их сотоварищей. Строгое повиновение учеников и снисходительное с ними обращение суть такие вещи, кои могут существовать вместе. Следовательно, строгость и снисходительность суть два главнейшие правила для надзирателей. Воспитание учеников их не должно быть рабское, но также и не обузданное.

59. b) Полиция

Сколько в фамилиях столь еще больше в таковых институтах нужно есть содержание доброго порядка, попечение о больных и распоряжение о экономической части. В наружном при целом Институте покоев и в дворе следует наблюдать величайшую чистоту. Кто часто выдывал такия учреждения в коих воспытиваются молодые люди в обществе, тому известно сколь много пренебреженна в оных чистота и неопрятность царствует даже до заразительности. Какое отвращение видют пятдесят или больше человек за одним большим столом вместе, накрытом нечистыми скатертями и уставленным прочим нечистотою своею отвратительным прибором! Возможно ли возбудить в них чувства чистоты воспитывая их в такой неопрятности и в такой нечистоте?

Экономическая часть должна быть в руках человека совестного, имеющаго собственных своих детей и который должен состоять под строгою контролою директора и надзирателей. Что принадлежит до внутренняго устройства и полиции в жилищах учеников их домашнего прилежания, внутреннего обхождения и проч., то все сие долженствует быть предоставленным благоразумию директора, который приемля на себя толь важную должность воспитывать толико большое число человек на пользу государства высокому званию своему только тогда соответствовать будет, когда оные для государства со временем с пользою могут быть употреблены.

Афанасий Стойкович 
Примерный штат учреждаемой в Нежине

Гимназии Безбородка высших наук.

\begin{tabular}{|l|r|}
\hline & Рубли \\
\hline Директору Гимназии & 800 \\
\hline Шести Старшим учителям каждому по 550 рублей & 3300 \\
\hline Четырем Младшим учителям 1. 2. 3. и 4. каждому по 500 рублей & 2000 \\
\hline Двум последним по 350 рублей & 700 \\
\hline На библиотеку & 300 \\
\hline На различные собрания, описанные в § 49м & 500 \\
\hline $\begin{array}{l}\text { Прибавочного жалованья Директору для присмотра за } 80 \text { воспитанниками и } \\
\text { который будет равно и Директором Института }\end{array}$ & 200 \\
\hline $\begin{array}{l}\text { Четырем надзирателям, которые будут и кои репетиторы, прибавочного по } \\
175 \text { рублей }\end{array}$ & 700 \\
\hline 80 питомцам на каждого содержанием по 175 рублей & 14000 \\
\hline На газеты и журналы для Гимназии и Института & 100 \\
\hline $\begin{array}{l}\text { На покупку разных инструментов, машин и орудий для предполагаемаго } \\
\text { мною телеснаго упражнения }\end{array}$ & 100 \\
\hline Двум учителям Уездного Училища по 325 рублей & 650 \\
\hline Учителю рисования & 50 \\
\hline Учителю Приходского Училища & 200 \\
\hline $\begin{array}{l}\text { На содержание домов Гимназических вообще, Института, служителей осве- } \\
\text { щение и прочее }\end{array}$ & 1900 \\
\hline
\end{tabular}

Афанасий Стойкович

ЦДІАК України, ф. 2162, оп. 1, спр. 34, арк. 12-36.

${ }^{1}$ Дана настанова про 60 вихованців за кошт гімназії повторювана кілька разів: Сборник постановлений по Министерству народного просвещения. - СПб., 1904. - Т. 1. - Царствование императора Александра I, 1802-1825. - С. 607.

2 Гімназією вищих наук заклад було вирішено назвати після повідомлення про щедуру пожертву Іллі Безбородька (Сборник постановлений по Министерству народного просвещения. - С. 429), Стойкович абсолютно зводить ніжинську гімназію до гімназійного навчального закладу з підпорядкуванням університету, що, звичайно, не передбачалося меценатами і прихильниками цього закладу.

3 Згідно 3 цим параграфом Статуту, в приходських училищах мали навчати: «чтению, письму и первым действиям арифметики, главным началам Закона Божия и нравоучения читают с объяснением книгу: Краткое наставление о сельском домоводстве, произведениях природы, сложении человеческого тела и вообще о средствах к предохранению здоровья» (Сборник постановлений по Министерству народного просвещения. - С. 359)

${ }^{4}$ За даним параграфом, оскільки Ніжин був містом, де жили «ремесляники и купцы и тому подобного состояния люди» (див. цю статутну вимогу: Сборник постановлений по Министерству народного просвещения. - С. 361), то заняття мали продовжуватися цілий рік, як у той же час в інших приходських училищах лише 6-7 «зимових» місяців.

5 До перерахованих в Статуті предметів (Сборник постановлений по Министерству народного просвещения. - С. 352) Стойкович додав психологію, геометрію, іноземні мови; вочевидь грецька мова подана Стойковичем як «місцева».

${ }^{6}$ Це власна пропозиція Стойковича, що не відповідає Статуту.

${ }^{7}$ Статутна пропозиція 30 годин на тиждень (Сборник постановлений по Министерству народного просвещения. - С. 334); Стойкович збільшує кількість годин.

${ }^{8}$ Італійська мова - це також позастатутна пропозиція Стойковича. 
${ }^{9}$ Це позастатутна пропозиція.

${ }^{10}$ Статут передбачав можливість гімнастичних вправ у гімназії, але після занять (Сборник постановлений по Министерству народного просвещения. - С. 335).

${ }^{11}$ Тут знову збільшення годин на грецьку (місцеву) мову.

${ }^{12}$ Історична допоміжна наука (нім), - це нова пропозиція Стойковича.

${ }^{13}$ П'ятий клас і предмети, що мали там викладатися - винятково пропозиції Стойковича.

${ }^{14}$ Йдеться про поширену книгу Biermann Georg Heinrich. Lehrbuch für den ersten Unterricht im Kopf und schriftlichen Rechnen (1803).

${ }^{15}$ Назву не вдалося прочитати.

${ }^{16}$ Одна із найвідоміших робіт Августа Людвіга Шльоцера («Підготовка світової історії для дітей»), що мала багато перевидань. Август Людвіг Шльоцер (August Ludwig von Schlözer) (1735$1809)$ - один із найвідоміших геттингенських професорів, що певний час перебував у Росії і висловив ряд думок щодо давньоруського минулого. Це черговий «реверанс» Стойковича до Геттингенського університету.

${ }^{17}$ Назву не вдалося прочитати.

18 У даному разі йдеться про витяги з підручників німецького педагога Карла Філліпа Функе (Karl Phillip Funke) (1752-1807 ), автора низки підручників для німецьких реальних шкіл.

19 Книжку не вдалося ідентифікувати.

${ }^{20}$ Автора не вдалося ідентифікувати.

${ }^{21}$ Стойкович вочевидь наводить прізвища відомих сучасних йому професорів з філософії права: Людвіга Якоба (Ludwig Jacob)(що пізніше став професором Харківського імператорського університету), Йоганна Федера (Johann Georg Heinrich Feder) - геттингенського професора філософії, Йоганна Кізеветтера (Johann Gottfried Kiesewetter) - популяризатора вчення Імануїла Канта, Готліба Тітеля (Gotlieb August Tittel) - автора окремих книг з логіки і метафізики, також популяризатора і критика філософії Канта.

${ }^{22}$ Напевно йдеться про книжку Йоахіма Ешенбурга (Joachim Eschenburg) Beispielsammlung zur Theorie der Schönen Wissenschaften у восьми томах (1788-1795).

${ }^{23}$ Тут деякі описки, йдеться про підручники Тимофія Осиповського (на той час професора Харківського університету), видані свого часу для народних училищ, геттингенського професора Авраама Кестнера (Abraham Kästner) - автора низки книжок для початківців у математиці, французького математика Етьєна Безу (Etienne Bezout).

${ }^{24}$ Назву не вдалося прочитати.

${ }^{25}$ Назву не вдалося прочитати.

${ }^{26}$ Йдеться про низку робіт для початків фізики геттингенського професора Йоганна Еркслебена (Johann Christian Erxleben) (1744-1777), словник для фізики французького фізика Матюрена Бріссона (Mathurin Jacques Brisson) (1723-1806) і досить відомий підручник для народних училищ Російської імперії «Руководство к физике» (1793) Петра Гіларовського.

${ }^{27}$ Вочевидь йдеться про праці з механіки берлінського математика Ернста Фішера (Ernst Gottfried Fischer) (1754-1831).

28 Текст пошкоджений, не можна ідентифікувати особу.

29 Тут вочевидь ідеться про твори баварського науковця Максімуса фон Імгофа (Maximus von Imhof) (1758-1817).

${ }^{30}$ Цих вчених не вдається ідентифікувати.

31 Идеться про праці основоположників сучасної хімії Антуана Лавуазьє (Antoine Lourent de Lavoisier) (1743-1794 ) та Антуана Фуркруа (Antoine Francois de Fourcroy) (1755-1809).

32 Цих вчених не вдається ідентифікувати.

33 Йдеться про роботи геттингенського професора історії Йоганна Гаттерера (Johann Christoph Gatterer) (1727-1799).

${ }^{34}$ Певно йдеться про роботу географа Адама Гаспарі (Adam Christian Gaspari) (1752-1830), на той час професора Дерптського університету.

${ }^{35}$ Guthrie William. Geographical, Historical, Commercial Grammar (1770).

${ }^{36}$ Матинский М. Всеобщее Землеописание для народных училищ... - СПб., 1788.

37 Янкович де Мириево Ф. Всемирная история для народных училищ... - СПб., 1787 (1800).

${ }^{38}$ Йдеться про роботи з всесвітньої та французької історії Клода Міло (Claude-François-Xavier Millot) (1726-1785) та з історії стародавнього світу Шарля Роллена (Charles Rollin) (1641-1721).

${ }^{39}$ Eshenburg Johann. Handbuch der klassischen Literatur (Berlin, 1783).

${ }^{40}$ Автор і перші слова назви нерозбірливі.

${ }^{41}$ Вочевидь йдеться про багатотомну Geographie der Griechen und Römer (1788-1824) професора з Нюрбербгу Конрада Маннерта (Konrad Mannert) (1756-1834).

${ }^{42}$ Це напевно робота Арнольда Геєрена (Arnold Hermann Ludwig Heeren) (1760-1842) Ideen über Politik, den Verkehr und den Handel der vornehmsten Völker der Alten Welt (1793-1796).

${ }^{43}$ Вочевидь йдеться про згадану вже книжку Янковича де Мірієво (Всемирная история для народных училищ). 
44 Див. примітку 38. Стойкович має на увазі численні огляди всесвітньої історії для дітей Йоганна Шрека (Johann Mattias Schrek) (1733-1808 ) та таблиці та підручники Юліуса Ремера (Julius August Remer) (1738-1803 ).

${ }^{45}$ Вочевидь йдеться про Йоганна Мойзеля (Johann Georg Meusel) (1743-1820) та його підручник Lehrbuch der Statistik (1792).

${ }^{46}$ Це вочевидь праці Матіаса Шпренгеля (Matthias Christian Sprengel) (1746-1801) та Сильвестра Лакруа (Sylvestre Lacroix) (1765-1843).

47 Зуев $B$. Начертание естественной истории для народных училищ...-СПб., 1786 (в 2-х книгах); Севергин В. Начальные основания естественной истории (в 2-х томах) (СПб., 1791).

${ }_{48}$ Йдеться про роботу Августа Бача (August Johann Georg Karl Batsch) (1761-1802) Versuch einer Anleitung zur Kenntniss und Geschichte der Pflanzen (1787-1788).

${ }^{49}$ Willdenow Karl. Grundriß der Kräuterkunde zu Vorlesungen (Berlin, 1792).

${ }^{50}$ Нерозбірливо, але вочевидь мова йде про відому книжку Карла Функе «Lesebüchern für Kinder, dem neuen Elementarbuch zum Gebrauche beim Privatunterricht in vier Theilen».

${ }^{51}$ Нерозбірливі перерахування розділів книги Функе.

52 Це роботи відомого геттингенського науковця Йоганна Бекманна (Johann Friedrich Beckmann (1739-1811) - автора терміну «технологія».

53 Ймовірно Крістіан Шпренгель (Christian Konrad Sprengel) (1750-1816) - засновник екологічних вчень, автор відомої книги «Entdecktes Geheimniss der Natur im Bau und in der Befruchtung der Blumen» (1793).

${ }^{54}$ Нерозбірлива назва книги.

55 Йдеться про кількатомні роботи 3 домашнього господарювання священника Крістіана Гермергаузена (Christian Friedrich Germerhausen) Hausvater (1783-1786) «Oekonomisches Reallexikon» $1795-1799$.

56 Повна назва книжки угорського ботаніка Людвіга Міттерпахера (Ludwig Mitterpacher) про рослинність в Угорщині. Elementa Rei Rusticae in Usum Academiarum Regni Hungariae Budae: Typis Regiae Universitatis, Anno MDCCLXXIX and M. DCC. XCIV(1779-1794).

${ }_{57}$ Вочевидь це книжка Йоганна Бекманна. Grundsatze der teutschen Landwirtschaft, 1769.

58 Це праці директора Ботанічного саду в Ляйпцігу Августина Вальтера (Augustin Friedrich Walther) (1688-1746) та вочевидь Anleitung zur sicheren Erziehung Holzarten (1787). Фрідріха Бургсдорфа (Friedrich August Ludwig von Burgsdorff).

${ }_{59}$ Цілком можливо йдеться про книжки Йоганна Швайгофера (Johann Michael Schweighoffer).

${ }^{60}$ Справжня назва книжки: Anleitung zur Handelwissenschaft (1789).

${ }^{61}$ Назву не ідентифіковано.

${ }^{62}$ Нерозбірливі назви книжок.

${ }^{63}$ Це книжка московського професора Івана (Бернгарда) Гейма. Руководство к коммерческой науке, в пользу высших классов гимназий, состоящих в округе Имп. Моск. Унив., М., 1804.

${ }_{64}$ Йдеться про роботу геттингенського професора Георга Сарторiyca (Georg Friedrich Sartorius) (1765-1828) «Handbuch der Staatswirtschaft zum Gebrauch bei akademischen Vorlesungen» (1796).

${ }^{65}$ Jakob Ludwig. Lehrbuch der Nationalökonomie (Halle, 1805). (1795).

${ }^{66}$ Можливо йдеться про книгу Артура Юнга (Arthur Young) «An idea of the present state of France»

${ }^{67}$ Вочевидь йдеться про роботи Юстуса Лодера (Justus Christian Loder) (1753-1832), професора i хірурга на той час в Йені, напевно, Стойкович і Лодер навчалися в Геттингені в один час.

${ }^{68}$ Не вдається ідентифікувати цю книжку.

69 Головин $M$. Краткое руководство к гражданской архитектуре и зодчеству, изданное для народных училищ Российской империи...--СПб., 1789.

${ }^{70}$ Нерозбірливо.

71 Напевно йдеться про книжки: Козельский Я. Механические предложения. - СПб., 1764 та Руководство к механике, изданное для народных училищ. - СПб., 1789 (приписується Михайлу Головіну).

${ }^{72}$ Йдеться про відомий популярний підручник з механіки Theatrum Machinarium oder Schauplatz der Heb-Zeuge (1725), що мав багато видань.

${ }^{73}$ Нерозбірливо.

74 Йдеться про знану роботу геттингенського професора математика Йоганна Маєра (Johann Tobias Mayer) (1723-1762).

75 Граматики Крістіана-Готтліба Бредера (Christian-Gottlieb Bröder) (1745-1819): «Praktische Grammatik der lateinischen Sprache» (1787) та «Kleine lateinische Grammatik» (1795) були основними підручниками для вивчення латини на значній частині німецьких земель.

${ }_{76}$ Не вдається ідентифівкувати цю книжку.

77 Вочевидь йдеться про навчальні книжки з латини П'єра Шомпре (Pierre Chompré) (1698-1760), зокрема збірник «Dictionnaire de la fable». 
${ }^{78}$ Тут йдеться про книжки та словники Йоганна Аделунга (Johann Christoph Adelung) (1732$1806)$, що сприяли формуванню і унормуванню німецької мови.

${ }_{79}$ Жак (Яків) Белен де Баллю (Jacques Nicolas Belin de Ballu) (1753-1815) професор словесності Харківського імператорського університету 1803-1811 рр., йдеться про той час упорядковану, але не опубліковану працю «Systema novum docendi et discendi linguam latinam» (Харків, 1806).

80 «Praktische französische Grammatik» (1799) Йоганна Майдінгера (Johann Valentin Meidinger) (1756-1822).

${ }^{81}$ Ноель Валльї (Noël François de Wailly) (1724-1801) французький лексикограф, автор основного на той час підручника французької мови «Principes généraux de langue française» (1754); Підручник Ресто було перекладено російською мовою: «Французкая грамматика собранная из разных авторов господином Ресто, а на российский язык переведенна Васильем Тепловым» (перше видання 1752 р.).

82 Тут йдеться про твори французького перекладача італійської літератури Жана Вінерона (Джованні Венероні) (Giovanini Veneroni) (1642-1708) та німецького літературознавця, популяризатора італійської літератури Кристіана Ягемана (Christian Joseph Jagemann) (1735-1804).

${ }^{83}$ Можливо Стойкович дещо помиляється, а йдеться про збірник Людвіга Iделера (Ludvig Ideler) та Гайнріха Нольте: Handbuch der französische Sprache und Literatur (Berlin, 1796).

${ }_{84}$ «Antologia poetica italiana» (2 Bd. 1776-1777)

${ }^{85}$ Безпосередньо Стойкович перераховує педагогів-філантропістів (Августа Німайера (August Hermann Niemeyer) (1754-1828), Жана Жака Руссо (Jean Jacques Roussou) (1712-1778), Йоганна Базедова (Johann Bernhard Basedow) (1723-1790), Фрідріха Резевітца (Friedrich Gabriel Resewitz) (17291806), Йоахіма Кампе (Joachim Campe) (1746-1818), Йоганна Гойзінгера (Johann Heinrich Gottlieb Heusinger) (1766-1837) - прихильників поєднання розумової та фізичної праці у вихованні, вочевидь такі підходи пасували самому Стойковичу.

${ }^{86}$ Нерозбірливо.

${ }^{87}$ Вочевидь йдеться про книжки основоположника і популяризатора орінтології Йоганна Бехштайна (Johann Matthäus Behstein) (1757-1822).

${ }^{88}$ Крістіан Готтгільф Зальцман (Christian Gotthielf Salzmann) (1744-1811) - педагог-філантропіст, засновник відомої школи сімейного типу в Шнепфенталі, автор низки пізнавальних книжок для «дітей та батьків». Стойкович, як видно, був залежним від педагогічних поглядів Зальцмана.

${ }^{89}$ Назву не вдалося прочитати.

${ }^{90}$ Напевно, йдеться про видання відомої класифікації тваринного та рослинного світу Карла Ліннея його супротивником Філліпом Міллером, що значно переробив і доповнив ту класифікацію.

${ }^{91}$ Назву не вдається прочитати.

${ }^{92}$ Нерозбірливо.

93 Даний розділ доповнює вимоги Статуту щодо іспитів учнів (Сборник постановлений по Министерству народного просвещения. - С. 347-348).

${ }_{94}$ У даному разі - це думки самого Стойковича. Однак слово Цензура тут означає - правила.

${ }^{95}$ Йдеться про параграфи щодо публічних іспитів учнів.

96 Тут вочевидь калька з французької - вищезаписані, написані.

${ }^{97}$ Це радше пропозиція Северина Потоцького, передбачалося утримувати 60 сиріт.

${ }_{98}$ У даному разі це слово означає «устрій» від німецького «die Polizei» і в свою чергу від грецького слова «ло́́ıı»». 